\title{
Communication
}

\section{MALDI-TOF MS Profiling of Annonaceous Acetogenins in Annona muricata Products for Human Consumption}

\author{
Pierre Champy $^{1, *}$, Vincent Guérineau ${ }^{2}$ and Olivier Laprévote ${ }^{2}$
}

1 Laboratoire de Pharmacognosie, CNRS UMR 8076 BioCIS, Faculté de Pharmacie, Université Paris-Sud 11, Rue J. B. Clément, 92296 Châtenay-Malabry, France

2 Équipe de Spectrométrie de Masse, Institut de Chimie des Substances Naturelles, CNRS UPR2301, 91198 Gif-sur-Yvette, France; E-Mails: vincent.guerineau@icsn.cnrs-gif.fr (V.G.); olivier.laprevote@icsn.cnrs-gif.fr (O.L.)

* Author to whom correspondence should be addressed; E-Mail: pierre.champy@u-psud.fr; Tel.: +33-146835639; Fax: +33-146835399.

Received: 20 October 2009; in revised form: 5 December 2009 / Accepted: 10 December 2009 / Published: 15 December 2009

\begin{abstract}
Annonaceous acetogenins are proposed as environmental neurotoxicants consumed through medicinal and alimentary habits and responsible for atypical parkinsonian syndromes observed in tropical areas. Potential sources of exposure still have to be determined, as, to date, only a few batches of products for human consumption were searched for these compounds. To assess the presence of acetogenins, we propose a fast, sensitive and accurate method of screening, using MALDI-TOF MS, with minimal sample preparation. Development of the technique is discussed. Its application to leaves of herbal tea, pulp and bottled nectar of Annona muricata is presented.
\end{abstract}

Keywords: Annona muricata; annonaceae; annonaceous acetogenin; annonacin; guadeloupean parkinsonism; MALDI-TOF MS

Abbreviations: $\alpha$-CHCA: $\alpha$-cyano-4-hydroxycinnamate; ACG: Annonaceous acetogenin; amu: atomic mass unit; APCI: atmospheric pressure chemical ionization; DAD: diode array detector; DHB: 2,5-hydroxybenzoyc acid; ESI: electrospray ionization; I.C.: internal calibrant; MALDI-TOF: Matrix-Assisted Laser Desorption/Ionization-Time-of-Flight; MS: mass spectrometry; NMR: nuclear magnetic resonance; RP-HPLC: reversed-phase high 
performance liquid chromatography; THAP: 2,4,6-trihydroxy-acetophenone; THF: tetrahydrofuran; THP: tetrahydropyran

\section{Introduction}

Ten years ago, The Lancet published an article relating the occurrence of a cluster of atypical parkinsonian syndromes in Guadeloupe (French West Indies) [1], where these patients account for two-thirds of all cases of Parkinsonism, compared to approximately 30\% in European countries. The disease was thoroughly characterized [2-5]. Autopsies revealed accumulation of neuronal Tau-fibrils $[2,6]$. This "Guadeloupean Parkinsonism" was epidemiologically linked to the consumption of plants of the Annonaceae family. Other clusters of atypical Parkinsonism were identified since then, in populations traditionally relying on Annonaceae [7-9]. Implication of inhibitors of mitochondrial complex I (NADH-ubiquinone oxydo-reductase) such as 1-methyl-4-phenylpyridinum, paraquat or rotenone in the occurrence of idiopathic Parkinsonism and their use to establish animal models of neurodegeneration have been extensively studied [10]. We showed Annonaceous acetogenins (ACGs) $[11,12]$, such as annonacin (ACG 6, see Figure 3), which are potent inhibitors of the enzyme, to be neurotoxic in vitro [13] and in vivo [14], in link with Tau [15,16]. Nevertheless, we determined presence of ACGs in leaves tea of Annona muricata L., which are of regular medicinal use in the Caribbean. More surprisingly, analysis revealed important concentrations in pulps and processed fruit juices of several edible Annona species (A. muricata, A. squamosa L.) [17,18]. Pomper et al. [19] identified three ACGs in the pulp of Asimina triloba Dunal., a cultivated Annonaceae of NorthAmerica; So did Chen et al. [20] and Liaw et al. [21] in unripe fruits of Rollinia mucosa (Jacq.) Baill. From this co-occurrence of data, the notion that ACGs could be etiological agents for cases of sporadic atypical Parkinsonism and tauopathy worldwide arose. Consequently, to identify sources of exposure (i.e., edible fruits and derived food products, traditional herbal remedies, dietary supplements), sensitive screening methods for unambiguous detection of ACGs are valuable.

ACGs displaying activity towards complex I are preferably extracted with $\mathrm{MeOH}$ or $\mathrm{CH}_{2} \mathrm{Cl}_{2}$. For batch to batch comparison in ACGs content, some authors rely on biological testing [2,19,22]. TLC revelation with Kedde reagent indicates presence of most ACGs (sub-type 1, i.e., with an unsaturated $\gamma$-methyl- $\gamma$-lactone), but not those with saturated lactones. Nevertheless, this method, although practical, lacks specificity and shows poor sensitivity. ${ }^{1} \mathrm{H}-\mathrm{NMR}$ examination of fractions is commonly used in the course of ACGs purification, based on a search for signals typical of the lactonic ring, but is hardly applicable to crude extracts. HPLC-DAD, because of low specificity at $\lambda=210 \mathrm{~nm}$, is of limited interest in the absence of standards. RP-HPLC-ESI(+)-MS/MS was successfully used for detection of ACGs in crude samples [23-25], but with low precision on mass measurements, and only few exploitable fragments. Dereplication of ACGs containing extracts often proves complex, because of co-elution of these numerous, closely structurally-related, compounds (at least 40-50 ACGs per extract, in our experience).

This prompted us to develop a simple tool for rapid, sensitive and accurate detection of ACGs in low amounts of crude extracts. Matrix-Assisted Laser Desorption/Ionization-Time-of-Flight (MALDI- 
TOF) MS is applicable to detection of trace compounds in complex mixtures, with low matrixes effects. Sample preparation and acquisition of data require minimal steps. HR measurements are possible [26]. The technique was previously used for quantification of annonacin in samples of $A$. muricata, using an internal standard [17], and for search of this molecule in brain parenchyma of annonacin-treated rats, after extraction and HPLC purification [14]. We here discuss the use of MALDI-TOF for qualitative study of ACGs in crude plant extracts, emphasizing on the choice of working conditions and internal calibrants. Application to several A. muricata products is shown. The results have chemotaxonomic and sanitary significance.

\section{Results and Discussion}

\section{Choice of MALDI-TOF parameters and mass calibration}

For ACGs, higher ionic intensities were obtained in the reflectron positive mode, with spectra displaying pairs of $[\mathrm{M}+\mathrm{Na}]^{+}$and $[\mathrm{M}+\mathrm{K}]^{+}$adducts, in a ratio of approximately 3:2. Adjunction of $\mathrm{LiCl}$ or $\mathrm{LiI}$ for formation of $[\mathrm{M}+\mathrm{Li}]^{+}$adducts, though previously used for structural determination and semiquantification of ACGs [27,28], did not prove particularly useful in our case. Among the different matrixes tested, THAP (2,4,6-trihydroxy-acetophenone) gave good results, but DHB (2,5hydroxybenzoyc acid) was preferred despite heterogeneous crystallization using the "dried droplet" method for deposit. Other working conditions and instrumental parameters were also optimized (see Experimental section). Ionic intensities for ACGs of types A (mono-THF) and B (bis-THF) was excellent, with 1.o.d. of about 200 fmoles deposited. Peaks resolution was satisfactory enough in these conditions ( $\mathrm{Rs} \sim 6,000-10,000)$. It is noteworthy that the soft ionization/desorption process in MALDI avoids typical in-source fragmentations observed in ESI or APCI-MS (i.e., losses of $\mathrm{H}_{2} \mathrm{O}, \mathrm{CO}_{2}$ ): Visualized ACGs thus are "native", and not due to artifactual $\mathrm{m} / \mathrm{z}$ shifts.

The following optimization steps were performed with annonacin, a mono-THF tetrahydroxylated ACG of sub-type $1 b\left(\mathrm{C}_{35} \mathrm{H}_{64} \mathrm{O}_{7}\right)$, with a methanolic extract of $A$. muricata leaves shown to contain this molecule as major ACG [17], and with combination of both. Internal calibration using matrix peaks (up to $\mathrm{m} / \mathrm{z} 275$ for DHB) gave unsatisfactory results, with errors on mass measurement of about 40-50 ppm. Internal calibrants (I.C.) of masses closer to that of ACGs (m/z: 590-700) were tested: Pepmix 5 (bradykinin [1-5] and [1-7], m/z: 573 and 757), flanks the zone of interest (Figure 1); PEG 400 peaks appear within the mass range of ACGs, with no overlap $\left(\Delta_{(m / z \text { calcd ACG- } m / z \text { calcd PEG })}>0.1 \mathrm{Th}\right)$. They gave similar results in terms of accuracy (Table 1): For the crude $\mathrm{MeOH}$ extract, both modes of internal calibration allowed very satisfactory measurements for $[\mathrm{M}+\mathrm{Na}]^{+}(<5 \mathrm{ppm})$ and $[\mathrm{M}+\mathrm{K}]^{+}(\sim 15 \mathrm{ppm})$ adducts of annonacin. However, use of PEG 400 necessitated complicated adaptation of dilutions for adequate intensity in regard to ACGs, peaks of moderate abundance disappearing from spectra when I.C. peaks were too prominent. Nevertheless, calibration step during treatment of data was easier for spectra acquired with Pepmix 5. Using this I.C., deviation on $\mathrm{m} / \mathrm{z}$ values for annonacin peaks, acquired from 15 spectra obtained from three independent experiments, was $\pm 0.0020 \mathrm{Th}$ (3.2 ppm). 
Table 1. Comparison of internal calibrants for mass measurement of annonacin $\left(\mathrm{C}_{35} \mathrm{H}_{64} \mathrm{O}_{7}\right)$ within a crude $\mathrm{MeOH}$ extract of $A$. muricata leaves (a) or alone (b).

\begin{tabular}{|c|c|c|c|c|c|c|}
\hline \multirow{2}{*}{ Calibration } & \multicolumn{3}{|c|}{$[\mathrm{M}+\mathrm{Na}]^{+}$} & \multicolumn{3}{|c|}{$[\mathbf{M}+\mathbf{K}]^{+}$} \\
\hline & $m / z_{\text {calcd }}$ & $m / z_{\text {meas. }}$ & error (ppm) & $m / \mathbf{z}_{\text {calcd }}$ & $m / \mathbf{z}_{\text {meas. }}$ & error (ppm) \\
\hline a: Pepmix 5 & \multirow{3}{*}{619.4550} & 619.4531 & 3.0 & \multirow{3}{*}{635.4289} & 635.4382 & 14.6 \\
\hline a: PEG 400 & & 619.4547 & 0.4 & & 635.4417 & 20.1 \\
\hline b: Pepmix 5 & & 619.4532 & 3.1 & & 635.4337 & 7.5 \\
\hline
\end{tabular}

Figure 1. Typical MALDI-TOF spectrum: $\mathrm{CH}_{2} \mathrm{Cl}_{2}$ fraction of aqueous $A$. muricata leaves extract (refluxed $\mathrm{H}_{2} \mathrm{O}$ ). m/z 400-1,000. I.C.: Pepmix 5.

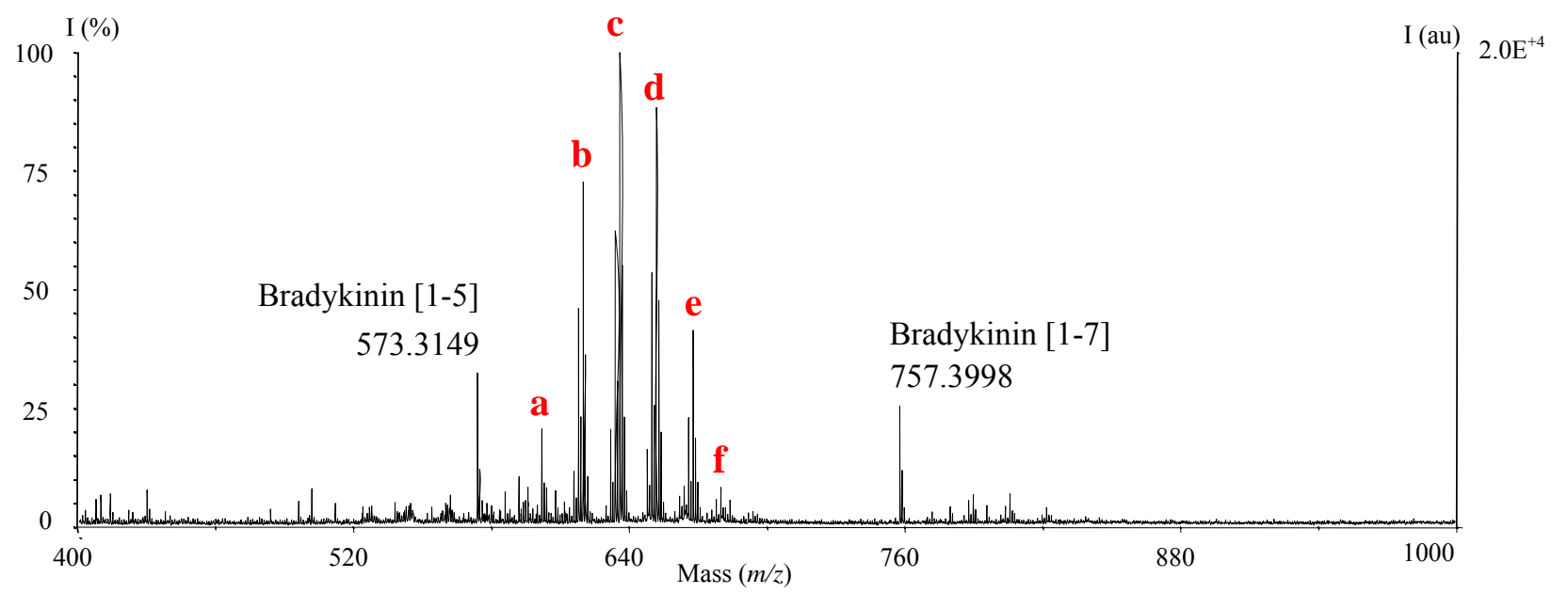

ACG peaks: a: Na2, Na3; b: Na4 to Na6, K2, K3; c: Na7 to Na9, K4 to K6; d: Na11, Na12, K7 to K9; e: Na13 to Na15, K11, K12; f: K13 to K15 (Na: $[\mathrm{M}+\mathrm{Na}]^{+}, \mathrm{K}:[\mathrm{M}+\mathrm{K}]^{+}$; See Table 2).

Table 2. Acetogenin peaks retrieved in crude extracts of Annona muricata derived products.

\begin{tabular}{|c|c|c|c|c|c|c|c|c|c|c|}
\hline \multirow{3}{*}{ Formula } & \multirow[b]{3}{*}{ Mass } & \multirow[b]{3}{*}{ Source } & \multirow{2}{*}{\multicolumn{4}{|c|}{$[\mathrm{M}+\mathrm{Na}]^{+}$}} & \multirow{2}{*}{\multicolumn{4}{|c|}{$[\mathbf{M}+\mathbf{K}]^{+}$}} \\
\hline & & & & & & & & & & \\
\hline & & & & $\boldsymbol{m} / \mathbf{z}_{\text {meas. }}$ & $m / z_{\text {calcd }}$ & error & & $\boldsymbol{m} / \mathbf{z}_{\text {meas. }}$ & $m / \mathbf{z}_{\text {calcd }}$ & error \\
\hline \multirow{2}{*}{$\mathrm{C}_{37} \mathrm{H}_{66} \mathrm{O}_{4}$} & \multirow{2}{*}{574.4961} & $\mathrm{p}$ & Na1 & 597.4801 & \multirow{2}{*}{597.4859} & 9.6 & \multirow{2}{*}{ K1 } & 613.4621 & \multirow{2}{*}{613.4598} & 3.7 \\
\hline & & $\mathrm{n}$ & & 597.4792 & & 11.2 & & 613.4510 & & 14.4 \\
\hline \multirow{2}{*}{$\mathrm{C}_{35} \mathrm{H}_{62} \mathrm{O}_{6}$} & \multirow{2}{*}{578.4546} & $*$ & $\mathrm{Na} 2$ & 601.4406 & \multirow{2}{*}{601.4444} & 6.4 & K2, & 617.4331 & \multirow{2}{*}{617.4183} & 23.9 \\
\hline & & $\mathrm{p}$ & & 601.4437 & & 1.2 & $\mathrm{Na5}$ & 617.4350 & & 27.0 \\
\hline $\mathrm{C}_{35} \mathrm{H}_{64} \mathrm{O}_{6}$ & 580.4703 & $*$ & Na3 & 603.4512 & 603.4601 & 14.6 & $\mathbf{K 3}$, Na6 & 619.4530 & 619.4340 & 30.6 \\
\hline \multirow{3}{*}{$\mathrm{C}_{35} \mathrm{H}_{60} \mathrm{O}_{7}$} & \multirow{3}{*}{592.4340} & $*$ & Na4 & 615.4194 & \multirow{3}{*}{615.4237} & 6.9 & \multirow{3}{*}{$\mathbf{K 4}, \mathrm{Na7}$} & 631.4152 & \multirow{3}{*}{631.3976} & 27.9 \\
\hline & & $\mathrm{p}$ & & 615.4255 & & 3.0 & & 631.4064 & & 13.9 \\
\hline & & $\mathrm{n}$ & & 615.4225 & & 1.8 & & 631.4030 & & 8.5 \\
\hline \multirow{3}{*}{$\mathrm{C}_{35} \mathrm{H}_{62} \mathrm{O}_{7}$} & \multirow{3}{*}{594.4496} & ht & $\begin{array}{l}\text { Na5, } \\
K 2\end{array}$ & 617.4331 & \multirow{3}{*}{617.4393} & 10.1 & \multirow{3}{*}{ K5, Na8 } & 633.4250 & \multirow{3}{*}{633.4133} & 18.5 \\
\hline & & $\mathrm{p}$ & & 617.4350 & & 6.9 & & 633.4246 & & 17.8 \\
\hline & & $\mathrm{n}$ & & 617.4407 & & 2.2 & & 633.4278 & & 22.9 \\
\hline \multirow{3}{*}{$\mathrm{C}_{35} \mathrm{H}_{64} \mathrm{O}_{7}$} & \multirow{3}{*}{596.4652} & ht & $\begin{array}{l}\text { Na6, } \\
K 3\end{array}$ & 619.4530 & \multirow{3}{*}{619.4550} & 3.2 & \multirow{3}{*}{$\mathbf{K 6}, \mathrm{Na} 9$} & 635.4382 & \multirow{3}{*}{635.4289} & 14.6 \\
\hline & & $\mathrm{p}$ & & 619.4510 & & 6.4 & & 635.4381 & & 14.4 \\
\hline & & $\mathrm{n}$ & & 619.4552 & & 0.1 & & 635.4406 & & 18.4 \\
\hline
\end{tabular}


Table 2. Cont.

\begin{tabular}{|c|c|c|c|c|c|c|c|c|c|c|}
\hline $\mathrm{C}_{35} \mathrm{H}_{60} \mathrm{O}_{8}$ & 608.4288 & $*$ & $\mathrm{Na} 7, \mathrm{~K} 4$ & 631.4152 & 631.4186 & 5.3 & K7 & 647.4011 & 647.3925 & 13.2 \\
\hline \multirow{3}{*}{$\mathrm{C}_{35} \mathrm{H}_{62} \mathrm{O}_{8}$} & \multirow{3}{*}{610.4445} & ht & \multirow{3}{*}{$\begin{array}{l}\text { Na8, } \\
\text { K5 }\end{array}$} & 633.4250 & \multirow{3}{*}{633.4342} & 14.6 & \multirow{3}{*}{ K8, Na11 } & 649.4149 & \multirow{3}{*}{649.4082} & 10.4 \\
\hline & & $\mathrm{p}$ & & 633.4246 & & 15.2 & & 649.4095 & & 2.1 \\
\hline & & $\mathrm{n}$ & & 633.4278 & & 10.2 & & 649.4142 & & 9.3 \\
\hline \multirow{3}{*}{$\mathrm{C}_{35} \mathrm{H}_{64} \mathrm{O}_{8}$} & \multirow{3}{*}{612.4601} & ht & \multirow{3}{*}{$\begin{array}{l}\text { Na9, } \\
\text { K6 }\end{array}$} & 635.4382 & \multirow{3}{*}{635.4499} & 18.4 & \multirow{3}{*}{ K9, Na12 } & 651.4291 & \multirow{3}{*}{651.4238} & 8.1 \\
\hline & & $\mathrm{p}$ & & 635.4381 & & 18.5 & & 651.4296 & & 9.3 \\
\hline & & $\mathrm{n}$ & & 635.4406 & & 14.6 & & 651.4344 & & 16.2 \\
\hline $\mathrm{C}_{37} \mathrm{H}_{66} \mathrm{O}_{7}$ & 622.4809 & $\mathrm{p}$ & Na10 & 645.4689 & 645.4706 & 2.6 & K10 & 661.4538 & 661.4446 & 13.9 \\
\hline \multirow{2}{*}{$\mathrm{C}_{35} \mathrm{H}_{62} \mathrm{O}_{9}$} & \multirow{2}{*}{626.4394} & ht & \multirow{2}{*}{ Na11, $K 8$} & 649.4149 & \multirow{2}{*}{649.4292} & 21.9 & \multirow{2}{*}{ K11 } & 665.4069 & \multirow{2}{*}{665.4031} & 5.8 \\
\hline & & $\mathrm{n}$ & & 649.4142 & & 23.0 & & 665.4083 & & 7.8 \\
\hline \multirow{2}{*}{$\mathrm{C}_{35} \mathrm{H}_{64} \mathrm{O}_{9}$} & \multirow{2}{*}{628.4550} & ht & Na12, & 651.4291 & \multirow{2}{*}{651.4448} & 24.1 & \multirow{2}{*}{ K12 } & 667.4178 & \multirow{2}{*}{667.4187} & 1.5 \\
\hline & & $\mathrm{p}$ & K9 & 651.4296 & & 16.0 & & 667.4142 & & 2.4 \\
\hline $\mathrm{C}_{37} \mathrm{H}_{64} \mathrm{O}_{8}$ & 636.4601 & $*$ & Na13 & 659.4312 & 659.4499 & 28.3 & K13 & 675.4328 & 675.4238 & 13.2 \\
\hline $\mathrm{C}_{37} \mathrm{H}_{66} \mathrm{O}_{8}$ & 638.4758 & $*$ & Na14 & 661.4609 & 661.4655 & 7.0 & K14 & 677.4458 & 677.4395 & 9.3 \\
\hline $\mathrm{C}_{37} \mathrm{H}_{68} \mathrm{O}_{8}$ & 640.4914 & $*$ & Na15 & 663.4749 & 663.4812 & 9.5 & K15 & 679.4530 & 679.4551 & 3.2 \\
\hline
\end{tabular}

Herbal tea (ht), pulp (p) and nectar (n); (*) peaks for refluxed $\mathrm{H}_{2} \mathrm{O}$ leaves extract, in addition to that of (ht); I.C.: Pepmix 5; Error (ppm).

\section{Treatment of data}

Molecular masses of ACGs can be easily predicted: these compounds are constituted of 35 or 37 carbon atoms, apart for few exceptions (short representatives, fatty acid esters). Seven lactonic subtypes are described [11,12] (for convenience, the former classification system for ACG [11] is used in this manuscript. Basically, variations on the alkyl chain reside in number of THF, THP, epoxides or ketones (+13.9792 amu compared to naked carbon backbone), hydroxyl groups (+15.9994 amu), acetyl moieties $\left(+\mathrm{C}_{2} \mathrm{H}_{2} \mathrm{O}:+42.0106 \mathrm{amu}\right)$. After calibration, interpretation of data can be achieved using a computer calculation table, and necessitates manual peaks selection. To accelerate this process, we developed a software allowing us to search for pairs of $m / z$ values corresponding to $[\mathrm{M}+\mathrm{Na}]^{+}$and $[\mathrm{M}+\mathrm{K}]^{+}$adducts, with desired maximal error on mass measurement and correct $\mathrm{S} / \mathrm{N}$ ratio $(>10)$, directly from the peaks list generated by the spectra treatment software. In the following experiments, criteria for precision were that determined for annonacin. It is noteworthy that the presence of isobaric ions leads to isobaric peaks of $\left[\mathrm{C}_{\mathrm{n}} \mathrm{H}_{\mathrm{m}} \mathrm{O}_{\mathrm{p}}+\mathrm{Na}\right]^{+}$and $\left[\mathrm{C}_{\mathrm{n}} \mathrm{H}_{\mathrm{m}} \mathrm{O}_{(\mathrm{p}-1)}+\mathrm{K}\right]^{+}$species $(\Delta \mathrm{Na}$ to $\mathrm{K}:+15.9793$ $\mathrm{amu})$. This competition explains the relative differences between experimental and calculated mass values for the most abundant species.

\section{Study of complex crude extracts}

The technique was applied to four $\mathrm{CH}_{2} \mathrm{Cl}_{2}$ extracts, prepared from the following A. muricata material:

- Refluxed $\mathrm{H}_{2} \mathrm{O}$ extract of ground leaves (Figure 1);

- Cup of herbal tea prepared from leaves, according to traditional recipe; In this particular case, the amount of $\mathrm{CH}_{2} \mathrm{Cl}_{2}$ extract obtained was low $(\sim 1 \mathrm{mg})$ and ACGs were undetectable with TLC or HPLC-UV, rendering our method particularly useful; 
- $\quad$ Lyophilized pulp from Senegal;

- Bottled nectar from Venezuela.

Details of typical spectra are shown in Figures $2 \mathrm{a}$ (herbal tea) and $2 \mathrm{~b}$ (pulp); $\mathrm{m} / \mathrm{z}$ values attributable to ACGs are presented in Table 2.

Figure 2. Typical MALDI-TOF spectra: (a) $\mathrm{CH}_{2} \mathrm{Cl}_{2}$ extract of herbal tea of A. muricata;

(b) $\mathrm{CH}_{2} \mathrm{Cl}_{2}$ extract of pulp of $A$. muricata. m/z: $595-675$ (ACG peaks: $\mathrm{Na}:[\mathrm{M}+\mathrm{Na}]^{+}, \mathrm{K}$ :

$\left.[\mathrm{M}+\mathrm{K}]^{+}\right)$; I.C.: Pepmix 5 .
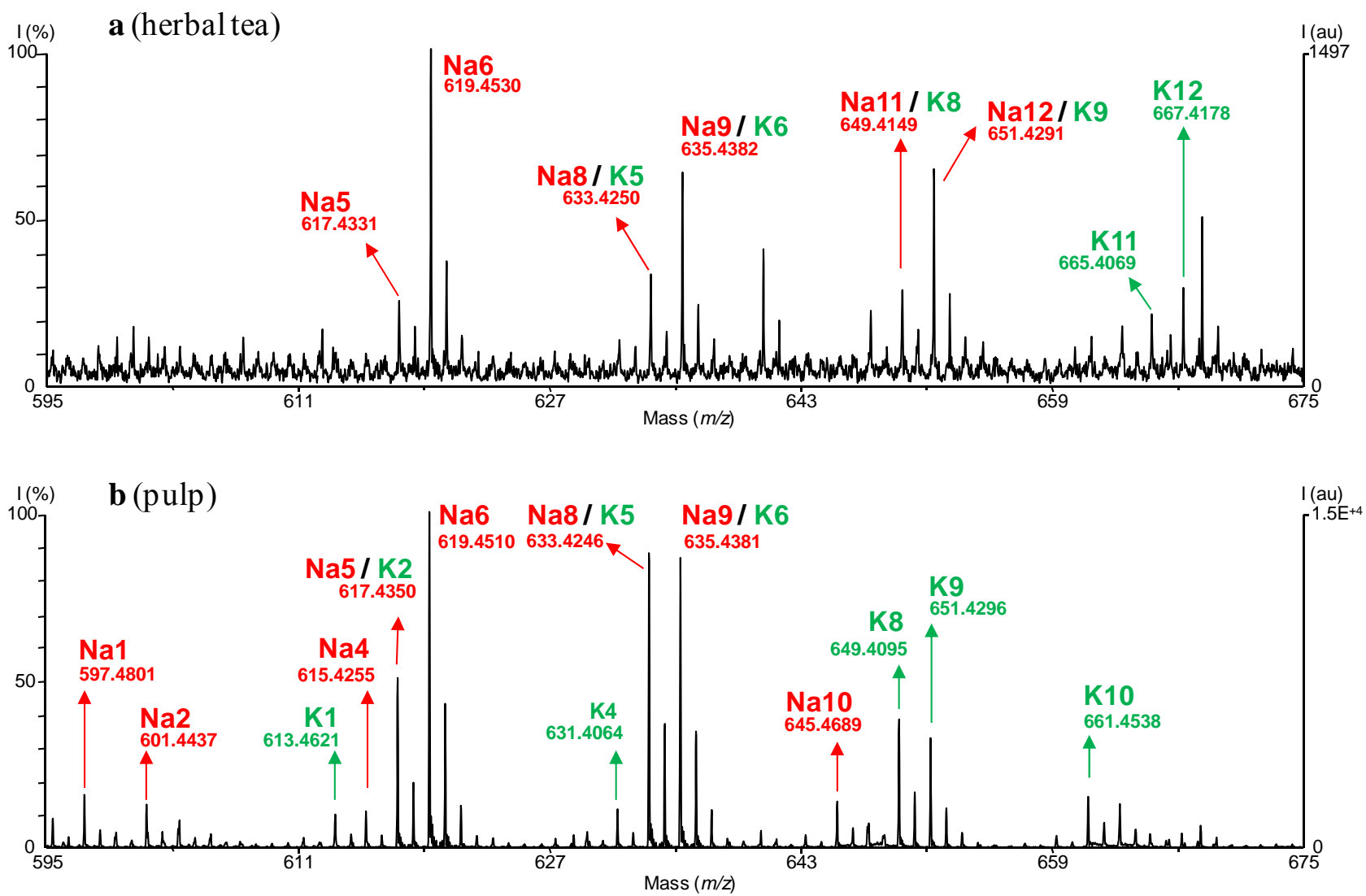

For each retrieved mass, numerous described or putative ACGs can be present. Representative structures are given (Figure 3), illustrating structural diversity among the class [12]. These examples were chosen in regard to their relevance, with the following criteria:

- Presence in A. muricata; Among ACGs isolated from the species: $\sim 60 \%$ bear OH at C-4, $45 \%$ at C-10; 65\% of type A bear an $\alpha, \alpha^{\prime}$-diOH-THF system between C-15 and C-20; $25 \%$ of type E (devoid of THF, e.g., 1a, 1b in Figure 3) are precursors of the latest [12,29];

- In case of absence in A. muricata: Presence in the genus Annona [12].

Interest of the method, chemotaxonomic significance

MALDI-TOF MS evidenced nine, seven and six masses/raw formula corresponding to ACGs in the pulp, nectar and leaves herbal tea, respectively. Seven minor groups of ACGs were observed in refluxed $\mathrm{H}_{2} \mathrm{O}$ leaves extract, in addition to that seen for herbal tea. A leaves crude $\mathrm{MeOH}$ extract showed identical qualitative pattern, with similar relative abundances (data not shown). 103 ACGs 
were isolated from $A$. muricata (bark, fruit, leaf, root and seed) so far [12,29]: 74\% bear 35 carbon atoms and $\sim 65 \%$ are of the A1 type (mono-THF, unsaturated lactone). Only one (non-adjacent) bisTHF and no tris-THF ACGs were isolated $[11,12]$. Most frequently cited raw formulas $\left(\mathrm{C}_{35} \mathrm{H}_{64} \mathrm{O}_{7}\right.$, $\sim 20 \%$ of ACGs described in the species; $\mathrm{C}_{35} \mathrm{H}_{64} \mathrm{O}_{8}, \sim 20 \%$ ) correspond to the most abundant groups in our analysis. Even though MALDI lacks quantitation capabilities in the absence of a standard [17], and though isolated compounds do not bear statistical witness of composition, our results are, interestingly, in remarkable agreement with the literature. The major peaks $(\mathrm{Na} 6 / \mathrm{K} 6)$ thus correspond to those of annonacin, often isolated from the plant, for all three samples [17]. $25 \%$ of ACGs described in the species belong to type E, mostly from seeds, which apolar extracts were extensively studied. Nearly none is visualized (10 un-retrieved peaks, e.g., $\mathrm{C}_{35} \mathrm{H}_{60} \mathrm{O}_{5},[\mathrm{M}+\mathrm{Na}]^{+}: \mathrm{m} / \mathrm{z}=583.4338,[\mathrm{M}+\mathrm{K}]^{+}$: $\mathrm{m} / \mathrm{z}=599.4078$, for corepoxylone, a putative precursor of annonacin [12]). Their near absence on spectra might be due to low abundance, low extraction yield and poor desorption rate.

It is also noteworthy that the peak patterns are not identical between the analyzed materials: only five masses/raw formula are shared (peaks Na4/K4 to Na6/K6, Na8/K8, Na9/K9). This is possibly in relation to chemotype and phenotypic discrepancies between organs. Accordingly, four raw formulas for type A1 ACGs found by others are absent, and three were un-described in the species, but identified in other Annona spp. (peaks Na4/K4, Na13/K13, Na15/K15). To our knowledge, the raw formula $\mathrm{C}_{35} \mathrm{H}_{60} \mathrm{O}_{8}$ (peaks Na7/K7) is not described among ACGs [11,12]. Lack of overlap of the $[\mathrm{M}+\mathrm{K}]^{+}$adduct $(\mathrm{K} 7)$ with a $\left[\mathrm{C}_{35} \mathrm{H}_{60} \mathrm{O}_{9}+\mathrm{Na}\right]^{+}$adduct rules out any artifactual nature for such compounds.

Figure 3. Structures of sub-type 1 ACGs possibly attributable to $m / z$ values identified (see Table 2).
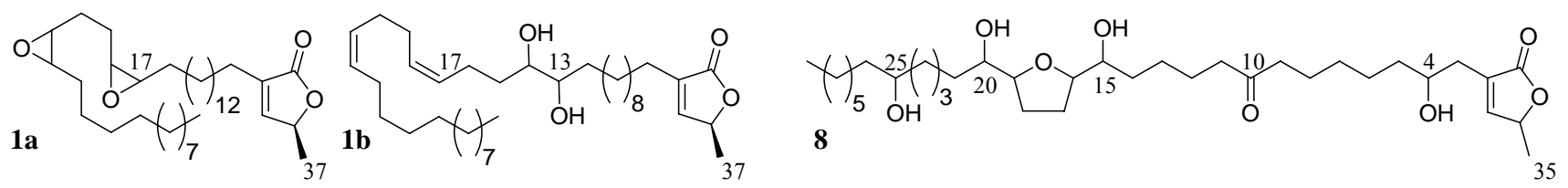

2<smiles>CCC(C)(C)C(C)(C)[C@H](O)[C@H]1CC[C@@H]([C@H](O)CCCCC(=O)CCCCCCCC2=C[C@H](S)OC2=O)O1</smiles>

3<smiles>CCC(C)(C)C[C@H](O)[C@@H]1CC[C@@H]([C@H](O)CCCC[C@H](O)CCCCCCCCC2=C[C@H](S)OC2=O)O1</smiles>

4

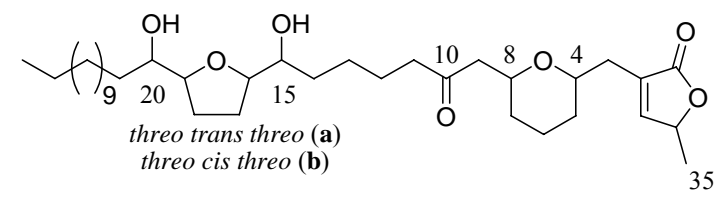

5

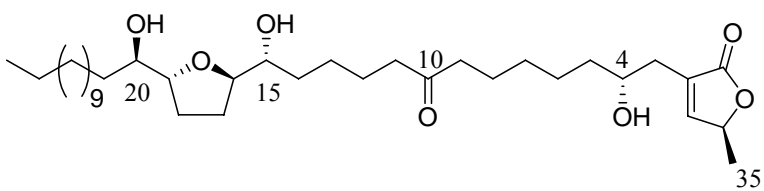

6

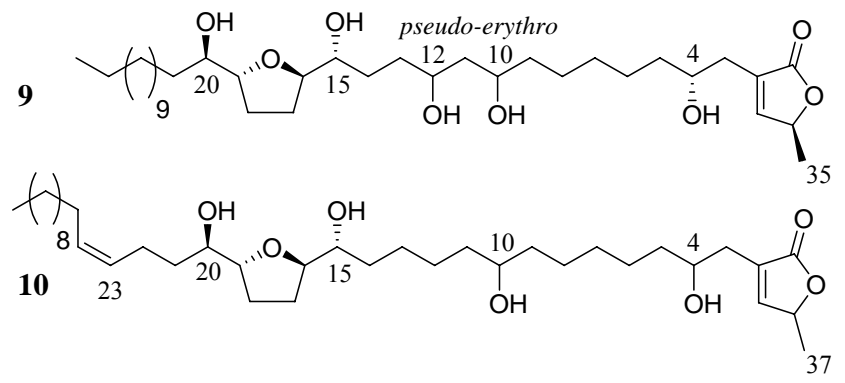

11

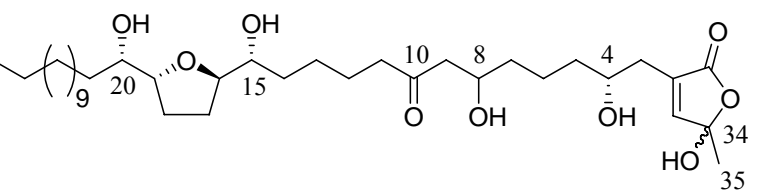

12

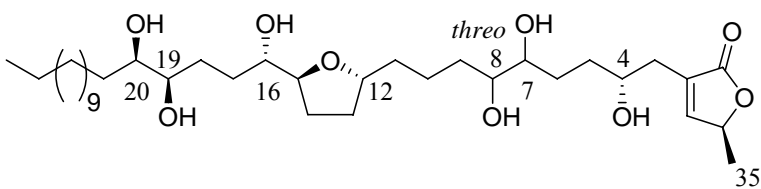

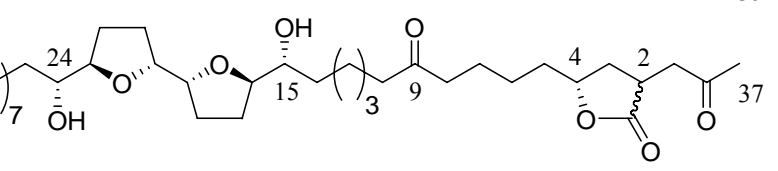


Figure 3. Cont.
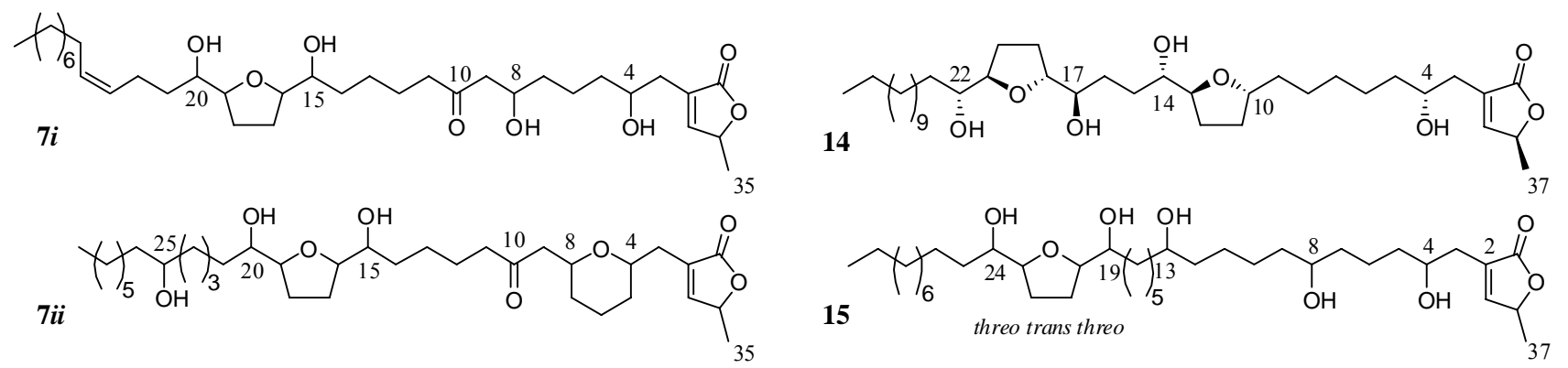

$\S$ described in A. muricata (organ); ${ }^{a}$ mono-THF ACGs can be proposed; ${ }^{b}$ bis-THF ACGs can be proposed; ${ }^{c}$ tris-THF ACGs can be proposed. [12] (for choice of displayed examples: see text). Na1/K1: $\mathrm{C}_{37} \mathrm{H}_{66} \mathrm{O}_{4} ; \S$ e.g., (1a) Dieporeticanin-1 (A. reticulata), (1b) montecristin (seeds) ${ }^{\mathrm{a}}$ [note that 1a is more likely to yield MS signals]; $\mathrm{Na} 2 / \mathrm{K} 2: \mathrm{C}_{35} \mathrm{H}_{62} \mathrm{O}_{6} ; \S$ e.g., (2) Corossolone (seeds) ; $^{\mathrm{b}}$; Na3/K3: $\mathrm{C}_{35} \mathrm{H}_{64} \mathrm{O}_{6}$; § e.g., (3) Corossolin (seeds); Na4/K4: $\mathrm{C}_{35} \mathrm{H}_{60} \mathrm{O}_{7}$; e.g., (4a, b) Montanacins-D \& -E (A. montana) $)^{\mathrm{c}}$, Na5/K5: $\mathrm{C}_{35} \mathrm{H}_{62} \mathrm{O}_{7} ;$ § e.g.: (5) Annonacinone (leaves) ${ }^{\text {b }} ;$ Na6/K6: $\mathrm{C}_{35} \mathrm{H}_{64} \mathrm{O}_{8}$; $\S$ e.g., (6) Annonacin (leaves); $\mathrm{Na} 7 / \mathrm{K} 7: \mathrm{C}_{35} \mathrm{H}_{60} \mathrm{O}_{8}$; undescribed, e.g., (7i, 7ii) Hypothetical ACGs

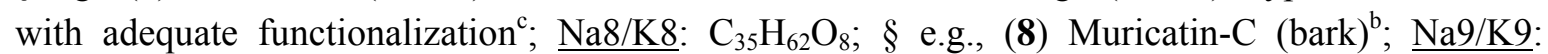
$\mathrm{C}_{35} \mathrm{H}_{64} \mathrm{O}_{8}$; § e.g.: (9) Muricatocin-A (leaves); Na10/K10: $\mathrm{C}_{37} \mathrm{H}_{66} \mathrm{O}_{7} ; \S$ e.g.: (10) Xylomatenin (A. senegalensis) ${ }^{\mathrm{b}}$; Na11/K11: $\mathrm{C}_{35} \mathrm{H}_{62} \mathrm{O}_{9} ; \S$ e.g.: (11) Montanacin-H \& 34-epi (A. montana) $)^{\mathrm{b}}$; Na12/K12: $\mathrm{C}_{35} \mathrm{H}_{64} \mathrm{O}_{9}$; $\S$ e.g.: (12) Murihexocin A (leaves); $\underline{\mathrm{Na} 13 / \mathrm{K} 13}: \mathrm{C}_{37} \mathrm{H}_{64} \mathrm{O}_{8}$; e.g.: (13) 9-oxoasimicinone (sub-type 2: extraction artifact from sub-type $1 \mathrm{~b}[30]$ - note that our working conditions are unlikely to give rise to such compounds; Other ACGs with this raw formula are not described) (A. squamosa) ${ }^{\mathrm{a}, \mathrm{c}}$; Na14/K14: $\mathrm{C}_{37} \mathrm{H}_{66} \mathrm{O}_{8} ;$ § e.g.: (14) Gigantecin (seeds) ${ }^{\mathrm{a}}$; Na15/K15: $\mathrm{C}_{37} \mathrm{H}_{68} \mathrm{O}_{8}$; e.g.: (15) Montanacin (A. montana).

\section{Experimental}

\section{General}

MALDI-TOF MS was performed with a Perseptive Voyager DE STR MALDI time-of-flight mass spectrometer (Perseptive Biosystems), equipped with a Tektronix TDS 540C digital oscilloscope $\left(500 \mathrm{MHz}\right.$, digitization rate 2 Gigasamples $\left.\cdot \mathrm{s}^{-1}\right)$ and with a $\mathrm{N}_{2}$ laser $(\lambda=337 \mathrm{~nm})$. Extraction solvents were purchased from Carlo-Erba (VWR) and MS solvents from Prolabo. Water was purified by a Millipore water purification system and had a resistivity $>18 \mathrm{M} \Omega \cdot \mathrm{cm}^{-1}$.

\section{Plant material and preparation of samples}

A. muricata fruits were purchased at a market in Dakar (Senegal), seeds and pericarps were removed and pulp was lyophilized, then extracted with $\mathrm{CH}_{2} \mathrm{Cl}_{2}$ (dry mass $=1 \mathrm{~g}$, vol $=50 \mathrm{~mL}$, r.t.; extract: $3.0 \mathrm{mg}$; plant material was devoid of seed fragments). A. muricata bottled nectar from Venezuela (vol: $520 \mathrm{~mL} ; 25 \%$ pulp), purchased in a food store in Paris, was diluted to $2 \mathrm{~L}$ with $\mathrm{H}_{2} \mathrm{O}$, then counter-extracted with $\mathrm{CH}_{2} \mathrm{Cl}_{2}(1: 1 \mathrm{v} / \mathrm{v}, 2 \times$; extract: $345.4 \mathrm{mg})$. Aqueous extracts of dried $A$. muricata leaves collected in Martinique (ground leaves $100 \mathrm{~g} / \mathrm{L}, \mathrm{H}_{2} \mathrm{O} 100{ }^{\circ} \mathrm{C}$, 3h, final yield: $0.2 \%$; 
entire leaves, $2.5 \mathrm{~g}$, infusion in $250 \mathrm{~mL} \mathrm{H} \mathrm{H}_{2} \mathrm{O}, 10 \mathrm{~min}$, final extract: $1.3 \pm 0.2 \mathrm{mg}$ ) were partitioned with $\mathrm{CH}_{2} \mathrm{Cl}_{2}(1: 1 \mathrm{v} / \mathrm{v}, 2 \times)$. Annonacin was obtained as previously described [14].

\section{MALDI-TOF experiments and data analysis}

Matrixes ( $\alpha$-cyano-4-hydroxycinnamate, $\alpha$-CHCA; 2,4,6-Trihydroxy-acetophenone, THAP; 2,5hydroxybenzoyc acid, DHB; Aldrich Chemical Co.) were tested in various solvents and concentrations. Further analyzes were performed with DHB in $\mathrm{MeOH} / \mathrm{H}_{2} \mathrm{O}(1: 1,20 \mathrm{mg} / \mathrm{mL})$. The samples $\left(10 \mathrm{mg} / \mathrm{mL}\right.$ in $\mathrm{MeOH}$ or $\left.\mathrm{CH}_{2} \mathrm{Cl}_{2}\right)$ were diluted in matrix solution $\left(1: 10, \mathrm{v} / \mathrm{v}, \mathrm{H}_{2} \mathrm{O} / \mathrm{MeOH} 1: 1\right)$. Deposit on the MALDI plate $(1 \mu \mathrm{L} / \mathrm{spot})$ was done, at least in triplicate, by the "dried droplet method" under atmospheric pressure. MALDI conditions were as follows: mass range: 100-1,000 or 400-1,000; low-mass gate: 80 or 350; laser power: 1,900-1,950 (arbitrary units); accelerating voltage: 20,000 V; grid voltage: $65 \%$ of accelerating voltage; delayed extraction time: $100 \mathrm{~ns}$; shots: $200-500 /$ spectrum.

Internal calibration was made by adding Pepmix 5 (1:20, v/v; bradykinin [1-5] and [1-7], $m / \mathrm{z}_{\text {calcd }}$ : 573.3150, 757.3998; LaserBio Labs $)$ or PEG $400\left(\sim 1: 10,000 \mathrm{v} / \mathrm{v}, \quad \mathrm{MeOH}, \quad \mathrm{m} / \mathrm{z}_{\text {calcd }}\right.$ : $\left[\mathrm{M}_{(\mathrm{n}=13)}+\mathrm{H}\right]^{+}=591.3592 ; \quad\left[\mathrm{M}_{(\mathrm{n}=13)}+\mathrm{K}\right]^{+}=613.3411 ; \quad\left[\mathrm{M}_{(\mathrm{n}=13)}+\mathrm{K}\right]^{+}=629.3150 ; \quad\left[\mathrm{M}_{(\mathrm{n}=14)}+\mathrm{H}\right]^{+}=635.3854 ;$ $\left.\left[\mathrm{M}_{(\mathrm{n}=14)}+\mathrm{Na}\right]^{+}=657.3673 ;\left[\mathrm{M}_{(\mathrm{n}=14)}+\mathrm{K}\right]^{+}=673.3413 ;\left[\mathrm{M}_{(\mathrm{n}=15)}+\mathrm{H}\right]^{+}=679.4116\right)$ to the samples mixed with matrix. Errors on mass measurement $\left[I\left(\mathrm{~m} / \mathrm{z}_{\text {meas. }} / \mathrm{m} / \mathrm{z}_{\text {calcd }}\right) \mid / \mathrm{m} / \mathrm{z}_{\text {calcd }} \times 10^{6}\right]$ were calculated in parts per million (ppm). For routine analyzes, a typical spectrum is chosen from two to five spectra acquired from each spot. Spectra were analyzed using the Data Explorer software (Perseptive Biosystems) and home-made software created with Windev $^{\circledR}$. For calculations: $\mathrm{Na}^{+}=22.9897697$ uma, $\mathrm{K}^{+}=38.9637090$ uma.

\section{Conclusions}

From these data, only hypothetical structures can be proposed, but MALDI-TOF MS offers valuable advantages: Sample preparation is minimal, desorption conditions are soft, sensitivity and mass accuracy are excellent, acquisition and interpretation of data are rapid (10 $\mathrm{min} / \mathrm{sample}$ ), no internal standard (i.e., purified ACG) is needed, making this technique an interesting screening tool for identification of ACGs in a public health context.

\section{Acknowledgements}

The authors wish to thank D. Fall and R. Duval for collection and treatment of plant material; C. Gleye, M. Ruberg, A. Laurens and R. Hocquemiller for their implication in this study; B. Figadère for prompting us to publish this work; G.U. Höglinger for his invaluable help in our joint Guadeloupean Parkinsonism research program; Referees for critical, thorough reading of the manuscript and for fruitful suggestions. They also express their gratitude to R. Champy for conceiving and programming the ACGs mass analysis software. Financial support was provided by the CNRS (Centre National de la Recherche Scientifique). 


\section{References and Notes}

1. Caparros-Lefèbvre, D.; Elbaz, A. Possible relation of atypical Parkinsonism in the French West Indies with consumption of tropical plants: A case-control study. Lancet 1999, 354, 281-286.

2. Caparros-Lefèbvre, D.; Sergeant, N.; Lees, A.; Camuzat, A.; Daniel, S.; Lannuzel, A.; Brice, A.; Tolosa, E.; Delacourte, A.; Duyckaerts, C. Guadeloupean Parkinsonism: A cluster of progressive supranuclear palsy-like tauopathy. Brain 2002, 125, 801-811.

3. Lannuzel, A.; Höglinger, G.U.; Verhaeghe, S.; Gire, L.; Belson, S.; Escobar-Khondiker, M.; Poullain, P.; Oertel, W.H.; Hirsch, E.C.; Dubois, B.; Ruberg, M. Atypical Parkinsonism in Guadeloupe: A common risk factor for two closely related phenotypes? Brain 2007, 130, 816-827.

4. De Cock, V.C.; Lannuzel, A.; Verhaeghe, S.; Roze, E.; Ruberg M.; Derenne, J.P.; Willer, J.C.; Vidailhet, M.; Arnulf I. REM sleep behavior disorder in patients with Guadeloupean Parkinsonism, a Tauopathy. Sleep 2007, 30, 1026-1032.

5. Apartis, E.; Gaymard, B.; Verhaeghe, S.; Roze, E.; Vidailhet, M.; Lannuzel, A. Predominant cortical dysfunction in Guadeloupean parkinsonism. Brain 2008, 131, 2701-2709.

7. Angibaud, G.; Gaultier, C.; Rascol, O. Atypical parkinsonism and Annonaceae consumption in New Caledonia. Mov. Disord. 2004, 19, 603-604.

6. Camuzat, A.; Romana, M.; Dürr, A.; Feingold, J.; Brice, A.; Ruberg, M.; Lannuzel, A. The PSPassociated MAPT H1 subhaplotype in Guadeloupean atypical parkinsonism. Mov Disord. 2008, 23, 2384-2391.

8. Chaudhuri, K.R.; Hu, M.T.M.; Brooks, D.J. Atypical parkinsonism in Afro-Caribbean and Indian origin immigrants to the U.K. Mov. Disord. 2000, 15, 18-23.

9. Steele, J.C.; Caparros-Lefèbvre, D.; Lees, A.; Sacks, O. Progressive supranuclear palsy and its relation to pacific foci of the parkinsonism-dementia complex and Guadeloupean Parkinsonism. Parkinsonism Relat. Disord. 2002, 9, 39-54.

10. Schapira, A.H.V. Mitochondrial dysfunction in Parkinson's disease. Cell Death Differ. 2007, 14, 1261-1266.

11. Cavé, A.; Figadère, B.; Laurens, A.; Cortes, D. Acetogenins from Annonaceae. In Progress in the Chemistry of Organic Natural Products; Herz, W., Kirby, G.W., Moore, R.E., Steglich, W., Tamm, C., Eds.; Springer: Vienna, New York, NY, USA, 1997; pp. 81-288.

12. Bermejo, A.; Figadère, B.; Zafra-Polo, M.C.; Barrachina, I.; Estornell, E.; Cortes, D. Acetogenins from Annonceae: Recent progress in isolation, synthesis and mechanisms of action. Nat. Prod. Rep. 2005, 22, 269-303.

13. Lannuzel, A.; Michel, P.P.; Höglinger, G.U.; Champy, P.; Jousset, A.; Medja, F.; Lombès, A.; Darios, F.; Gleye, C.; Laurens, A.; Hocquemiller, R.; Hirsch, E.C.; Ruberg, M. The mitochondrial complex I inhibitor annonacin is toxic to mesencephalic dopaminergic neurons by impairment of energy metabolism. Neuroscience 2003, 121, 287-296.

14. Champy, P.; Höglinger, G.U.; Féger, J.; Gleye, C.; Hocquemiller, R.; Laurens, A.; Guérineau, V.; Laprévote, O.; Medja, F.; Lombès, A.; Michel, P.P.; Lannuzel, A.; Hirsch, E.C.; Ruberg, M. Annonacin, a lipophilic inhibitor of mitochondrial complex I, induces nigral and striatal 
neurodegeneration in rats: Possible relevance for atypical parkinsonism in Guadeloupe. $J$. Neurochem. 2004, 88, 63-69.

15. Escobar-Khondiker, M.; Höllerhage, M.; Michel, P.P.; Muriel, M.P.; Champy, P.; Yagi, T.; Lannuzel, A.; Hirsch, E.C.; Oertel, W.H.; Ruberg, M.; Höglinger, G.U. Annonacin, a natural mitochondrial complex I inhibitor, causes Tau pathology in cultured neurons. J. Neurosci. 2006, 27, 7828-7837.

16. Höllerhage, M.; Matusch, A.; Champy, P.; Lombès, A.; Ruberg, M.; Oertel, W.H.; Höglinger, G.U. Natural lipophilic inhibitors of mitochondrial complex I are candidate toxins for sporadic tau pathologies. Exp. Neurol. 2009, 14, 4387-4395.

17. Champy, P.; Melot, A.; Guérineau, V.; Gleye, C.; Höglinger, G.U.; Ruberg, M.; Lannuzel, A.; Laprévote, O.; Laurens, A.; Hocquemiller, R. Quantification of acetogenins in Annona muricata linked to atypical parkinsonism in Guadeloupe. Mov. Disord. 2005, 20, 1629-1633.

18. Champy, P.; Escobar-Khondiker, M.; Bajin ba Ndop, I.; Yamada, E.; Lannuzel, A.; Laprévote, O.; Ruberg, M.; Höglinger, G.U. Atypical parkinsonism induced by Annonaceae: Where are we yet? Planta Med. 2008, 74, 936-937.

19. Pomper, K.W.; Lowe, J.D.; Crabtree, S.B.; Keller, W.J. Identification of Annonaceous Acetogenins in the ripe fruit of the North American pawpaw (Asimina triloba). J. Agric. Food Chem. 2009, 57, 8339.

20. Chen, Y.Y.; Chang, F.R.; Yen, H.F.; Wu, Y.C. Epomusenins A and B, two acetogenins from the fruits of Rollinia mucosa. Phytochemistry 1996, 42, 1081-1083.

21. Liaw, C.C.; Chang, F.R.; Wu, M.J.; Wu Y.C. A novel constituent from Rollinia mucosa, rollicosin, and a new approach to develop Annonaceous acetogenins as potential antitumor agents. J. Nat. Prod. 2003, 66, 279-281.

22. McLaughlin, J.L. Paw Paw and Cancer: Annonaceous acetogenins from discovery to commercial products. J. Nat. Prod. 2008, 71, 1311-1321.

23. Gu, Z.M.; Zhou, D.; Lewis, N.; Wu, J.; Shi, G.; McLaughlin, J.L. Isolation of new bioactive Annonaceous acetogenins from Rollinia mucosa guided by liquid chromatography/mass spectrometry. Bioorg. Med. Chem. 1997a, 5, 1911-1916.

24. Gu, Z.M.; Zhou, D.; Wu, J.; Shi, G.; Zeng, L.; McLaughlin, J.L. Screening for Annonaceous acetogenins in bioactive plants extracts by liquid chromatography/mass spectrometry. J. Nat. Prod. 1997b, 60, 242-248.

25. Martin, J.M.; Madigosky, S.R.; Gu, Z.M.; Zhou, D.; Wu, J.; McLaughlin, J.L. Chemical defense in the zebra swallowtail butterfly, Eurytides marcellus, involving Annonaceous acetogenins. J. Nat. Prod. 1999, 62, 2-4.

26. Koomen, J.M.; Russell, W.K.; Tichy, S.E.; Russell, D.H. Accurate mass measurement of DNA oligonucleotide ions using high-resolution time-of-flight mass spectrometry. J. Mass Spectrom. 2002, 37, 357-371.

27. Laprévote, O.; Girard, C.; Das, B.C.; Cortes, D.; Cavé, A. Formation of gas-phase lithium complexes from acetogenins and their analysis by fast atom bombardment mass spectrometry. Tetrahedron Lett. 1992, 33, 5237-5240. 
28. Laprévote, O.; Girard, C.; Das, B.C.; Cortes, D.; Cavé, A. Desorption of lithium complexes of acetogenins by fast atom bombardment: Application to semi-quantitative analysis of crude plant extracts. Analusis 1993, 21, 207-210.

29 Melot, A.; Fall, D.; Gleye, C; Champy, P. Apolar Annonaceous acetogenins from the fruit pulp of Annona muricata. Molecules 2009, 14, 4387-4395.

30. Duret, P.; Laurens, A.; Hocquemiller, R.; Cortes, D.; Cavé, A. Isoacetogenins, artifacts issued from translactonization from Annonaceous acetogenins. Heterocycles 1994, 39, 741-749.

Sample Availability: Not Available.

(C) 2009 by the authors; licensee Molecular Diversity Preservation International, Basel, Switzerland. This article is an open-access article distributed under the terms and conditions of the Creative Commons Attribution license (http://creativecommons.org/licenses/by/3.0/). 